\title{
obituary
}

\section{J. B. Conant, 1893-1978}

James Bryant Conant, notable American chemist, innovative president of Harvard University, organiser and principal leader of the American wartime technological efforts, postwar science statesman, ambassador to Germany and at the age of seventy the most influential but controversial school reformer, died at the age of eighty-four on 11 February, 1978 after a long illness. He leaves behind his wife, née Grace Thayer Richards, whom he married in 1921, two sons and five grandchildren.

Jim Conant, the son of a photoengraver, was born in Dorchester (now a part of Boston) on 26 March 1893 was educated in local public schools and entered Harvard college in 1910. He planned his undergraduate curriculum for a career in chemistry, completed the four-year course with distinction in three and yet found time to be the editor of the Harvard Crimson, the undergraduate daily paper.

His graduate work was also at Harvard and led to a Ph.D. degree in 1916. It combined a project in physical chemistry under Professor T. W. Richards, the Nobel laureate known for his atomic weight determinations and a synthetic organic problem under Profesor E. P. Kohler. Then followed war work, involving research on the synthesis of Lewisite, an arsenical poison gas, and the construction of a plant to manufacture it.

Conant returned to Harvard in 1919 as an instructor in organic chemistry. Organic chemistry then was totally dominated by European scientists: Richard Willstätter, Leopold Ruzicka, Emil Fischer, Robert Robinson, Arthur Lapworth, and many others. Conant, almost alone among American chemists, came to the forefront of both major thrusts of organic chemistry, natural products and fundamental theory. Although he himself regarded his research on the structure of chlorophyll as most significant, his contributions to physical-organic chemistry had a much greater impact on subsequent developments, since Conant's ideas and discoveries stimulated rapid progress in the understanding of reaction mechanisms.

In particular, he and N. F. Hall introduced the concept of superacidity

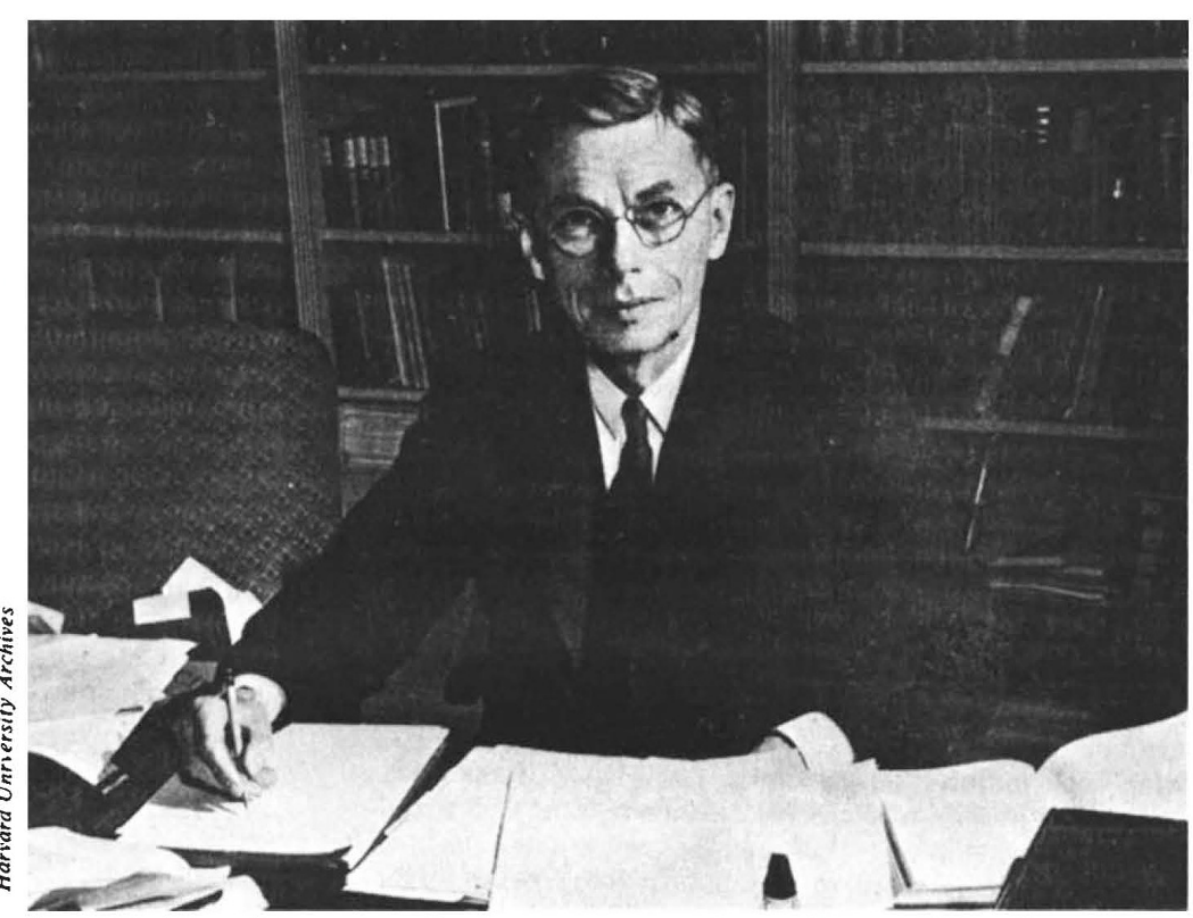

for solutions of strong acids in nonaqueous solvents. With $G$. M. Gramann Conant showed that both sodium acetate and perchloric acid strongly catalyse the acetylation of $\beta$ naphthol in acetic acid. Sodium acetate had, of course, already been used by synthetic chemists as a catalyst, but the understanding that it functions as a strong base in acetic acid as solvent was of fundamental importance to future work. Conant and G. W. Wheland initiated the quantitative treatment of extremely weak acids such as cyclopentadiene, using triphenylmethyl sodium in ether as the needed strong base. These were germinal contributions to the theory of non-aqueous solutions.

Conant's investigations with L. F. Fieser, among others, of the reversible oxidation-reduction potentials of quinones, and his studies of irreversible electrochemical oxidations and reductions were far ahead of their time. In his work with P. D. Bartlett on the mechanism of semicarbazone formation, he distinguished clearly between kinetic and thermodynamic controls and that paper exerted a powerful influence on developing theory. He and Professor P. W. Bridgman were the first to investigate the effects of extremely high pressures on the rates of organic reactions, discovering a striking acceleration of polymerisations.

Among Conant's contributions in the biochemical area was the discovery of copper in the prosthetic group of hemocyanin, the oxygen-carrying pigment of the blood of crustaceans. In his major biochemical work, Conant and his collaborators discovered the role of autoxidation in the so-called 'phase test' for chlorophyll - a complex and previously confusing series of reactions initiated by strong bases. Although Conant's part in the chlorophyll story was not the central one, Hans Fischer having proposed in 1935 a substantially correct structure, one can only speculate as to what Conant might have accomplished had he not been elected president of Harvard in 1933. Also in that year appeared the first edition of his influential textbook, The Chemistry of Organic Compounds; he had already been the editor-in-chief of the second volume of the internationally acclaimed series Organic Syntheses.

As president of Harvard University Conant still found time to maintain an active interest in chemistry. Thus he participated in the interpretation of the heats of organic reactions being measured by a group led by G. B. Kistiakowsky and he stimulated a group led by A. B. Hastings and 
G. B. Kistiakowsky to apply the shortlived ${ }^{11} \mathrm{C}$, the only radioactive isotope of carbon then available, to a study in depth of a metabolic pathway in the liver.

During the thirteen years that Conant was an academic chemist more than sixty young men and women published research papers with him. Several among his students became distinguished academic scientists: $\mathbf{P}$. D. Bartlett, L. F. Fieser, A. M. Pappenheimer, Frank Westheimer at Harvard, G. W. Wheland at the University of Chicago, J. G. Astin at the Pennsylvania State University, A. Corwin at Johns Hopkins University, and others.

Entering the presidency, Conant found Harvard little more than a New England college; he left it twenty years later the leading national university. Throughout life Conant was a scholar dedicated to research and the measures he introduced at Harvard emphasised research and graduate education as comparable in importance with undergraduate instruction. A major role in this transformation was the limitation of all non-tenure faculty appointees to a maximum of eight years and the introduction of ad hoc committees composed mainly of scholars from other institutions to screen all candidates for tenure appointments at Harvard on the basis of their scholarly contributions. Many American universities subsequently adopted similar rules and procedures.

Conant created the University Professorships to free a few distinguished faculty scholars from routine duties. $\mathrm{He}$ thoroughly reorganised the Harvard engineering school into a Division of Applied Physics and Engineering Sciences. Through his selection and encouragement of Francis Keppel as the Dean of a limping Graduate School of Education the latter was transformed into the leading centre for the training of school administrators.

Among the many reforms introduced into the undergraduate education the most important were those proposed in the 1945 faculty report General Education in a Free Society. This report, known as the 'Red Book', exercised great influence on educational programmes in colleges throughout America. Conant also created National Scholarships at Harvard for needy students from all parts of the United States to broaden the student body from one of predominantly New England origin. After the war he eliminated separate lectures and laboratory instruction for the Harvard and (female) Radcliffe undergraduates.

In the intercollegiate ('varsity') sports, which play a large role in American colleges, Conant replaced an autonomous body led by the alumni association, which is the norm in American universities and is the source of athletic scholarships, by a departmental structure administered by a faculty committee. The scholarships to athletes qua athletes were eliminated.

In the late thirties Conant was the first academic leader in America to join a public debate and urge military preparedness in the face of threats posed by Hitlerism. In the fall of 1939 he was already discussing ways by which American scientists could assist the British war effort, thus also preparing themselves for the time when their technical services would be needed at home. Next spring he joined Vannevar Bush in organising the National Defense Research Committee (NDRC), a civilian organisation felt to be necessary because the American military research establishment was wholly fossilised by neglect and lack of funds.

Conant became the head of the chemical division of NDRC, but, as he told me then, he knew that 'World War I was the war of the chemists, this one will be the physicists' war' and so he advised me to concern myself with explosives and ordnance, not chemical warfare.

The politics of American isolationism and the dangers of trans-Atlantic travel in 1940 engendered strong opposition to Conant's proposal to establish a systematic exchange of technical information and personnel between NDRC and the British military-technical establishment. Conant overcame the opposition and in February 1941 led a mission to England, where he was hailed as a messenger of hope by the beleaguered nation. The task of establishing effective channels of information exchange was quite complex because the United States was still expressly neutral, because NDRC was a young organisation composed largely of non-government civilians and because at that time the information had to flow mostly one way, westward. the British military technology being well-ahead. Conant succeeded in overcoming these obstacles beyond his own fondest hopes. In the process he was received by the King, had two meetings and meals with the Prime Minister and established cordial relations with the leaders of the British military-technical establishment.

Departing England a month later, having had an automobile accident while being driven to Chequers by Professor R. G. W. Norrish, also 'flu and a severe head cold induced by overwork and under-heated rooms, he left behind a working London NDRC liaison office. This group became highly effective in ferreting out information and in smoothing the way for visiting American scientists and engineers who followed Conant as a trickle in the spring of 1941 that grew to a flood in later years.

In the meantime the NDRC organisation grew fast; President Roosevelt, to emphasise its importance, created a parent body, the Office of Scientific Research and Development, a part of the White House staff. Bush became its director. Conant his deputy and his successor as the chairman of NDRC. While Bush was mainly involved in the high councils of government and managing the relations between NDRC and the military. Conant became the head organiser and a hard-driving manager of a great variety of warrelated NDRC projects numbering into the thousands.

The largest group efforts went probably into microwave radar, sonar, electronic countermeasures, proximity fuses, barrage rockets, aids to amphibious operations, a new process for manufacturing and using the British RDX explosive and, of course, uranium fission, which, however, soon ceased to be a part of NDRC. To mid1943. Conant was the chairman of a special committee administering the uranium project and he took personal responsibility for the big gamble of nearly direct transition from laboratory scale work to the giant industrial establishments for the production of fissionable materials. When General L. E. Groves took over for the Army Corps of Engineers in 1943, a top level Military Policy Committee was established by Roosevelt, chaired by Bush with Conant his alternate, to which General Groves was to report. It fell to Conant to monitor the progress of the complex parts of what became known as the Manhattan District and to resolve conflicts between 'the most colossal egos' with whom he ever had to deal, as he once confided to me. To Groves Conant appeared to have the courage of his Yankee forebears.

At war's end Conant returned to Harvard expecting to be again its fulltime president. Washington, however, had other plans for him. He was persuaded to accompany Secretary of State Byrnes to Moscow to negotiate agreement on international control of atomic energy which Conant advocated strongly. To the visitors' surprise the Soviet government accepted the American proposals. Had not the other Soviet-American confrontations induced President Truman to withdraw his support of Byrnes' initiative, the future course of Soviet-American relations might have been quite different.

Conant also became active in the debate on the structure of the American atomic energy establishment, supporting the proposals of the May- 
Johnson bill, then before Congress. This earned him the enmity of the liberal wing of atomic scientists who regarded this bill as militaristic. The May-Johnson bill was vetoed by President Truman and later the Atomic Energy Commission of the McMahon bill came into being. Conant was appointed a charter member of its General Advisory Committee which, for several years to follow, was a very influential group chaired by Oppenheimer. He joined the latter in opposing crash development of the 'super', the hydrogen bomb. When Oppenheimer was threatened with the loss of his military security clearances, being accused of indiscretions such as friendship with some members of the American Communist party, by the military and civilian proponents of the $H$-bomb, led by Edward Teller, Conant took a strong stand and testified on Oppenheimer's behalf at the scandalous hearings before an AEC security board that led to Oppenheimer's dismissal.

Conant became convinced during the war that to insure social progress the Federal Government in peacetime must finance basic scientific research in academic institutions and not do it through its military agencies, because of their secrecy requirements and emphasis on short range goals. At Harvard he established the rule that all faculty research must be open to publication thus closing the doors to most military research contracts. In Washington he took an active part in Congressional hearings which eventually led to the establishment of the National Science Foundation in 1949. Conant became the chairman of its policy-making body, the National Science Board. There he played an important role in the development of NSF policies and procedures in support of basic research which have largely survived to this day.

Conant was offered and accepted the nomination to the presidency of the National Academy of Sciences. However, the liberal elements among atomic scientists disapproved of his stand on the bombing of Japan and his position on the structure of the atomic energy agency. Other elements of the scientific community, including those who were attacking Oppenheimer, were resentful of Conant because of decisions he took in the course of his firm leadership of NDRC and the Manhattan project. Discovering the coalescence of these enmities into open opposition Conant withdrew his candidacy, to a grave disappointment of his many friends. Two years later he retired from the presidency of Harvard, to be appointed United States High Commissioner for Germany and this signaled the end of all his ties with the scientific community.

For four years, as the High Commissioner and then the Ambassador in Bonn, Conant worked effectively with Konrad Adenauer to transform defeated Germany into the Federal Republic, a cornerstone of the NATO alliance.

Sensing this task accomplished Conant returned to the United States in 1957 to embark on the last major career of his extraordinary life. While as president of Harvard he wrote and spoke frequently on problems of college education, Conant turned now to American high schools, assisted by a grant from the Carnegie Foundation. That happened at the time of the Sputnik when doubts about the adequacy of American education were rampant in the United States.

Two years later his book The American High School came out and soon more than 250,000 copies of it were in circulation. The book contained explicit recommendations for improving education and Conant embarked op nationwide travels strenuously campaigning for these reforms.

In 1961 Conant published an angry book Slums and Suburbs, in which, well ahead of the widespread unrest of the late sixties, he warned that the growing numbers of school dropouts and other unemployed urban youths in congested slums constituted a growing charge of social dynamite. This book caused Conant to be attacked by many black leaders because he advocated jobs ahead of school integration. As Conant notes in his autobiography his mistake was not to seek 'alliance with those black leaders who found my book objectionable.'

Two years later came the publication of his last book of this period, The Education of American Teachers, dealing with what he regarded as their scandalously low educational standards. As Conant anticipated the entire school teachers' establishment rose in arms to attack him furiously, but some reforms did follow later.

Prior to final retirement Conant spent two years in West Berlin as the advisor to that city's government, on an educational project financed by the Ford Foundation, and then returned to the United States to have a second look at public schools and publish his findings. Altogether he wrote ten books dealing with public education in addition to those on chemistry. He died in Hannover, New Hampshire, his summer home.

What remains now is the astonishing record of a man who lived many lives and achieved much in each. Conant was one of the principal architects of the American scientific edifice. He combined inborn conservatism with great intellectual boldness and the courage of his convictions when dealing with educational problems. As a high level manager of $\mathrm{R} \& \mathrm{D}$ he had an unerring feeling for what was right and wrong. He was a cool Yankee and yet could be a warm friend. The presence of Jim Conant made an indelible mark on this century's America.

G. B. Kistiakowsky

\section{G. J. Bramwell}

Geoffrey John Bramwell, Lecturer in Pharmacology in the Department of Pharmacy, Nottingham University, died of leukaemia on 13 April 1978, at the age of 31. Born at Leamington Spa, he was educated at Warwick School and the School of Pharmacy, London, where he graduated in 1969 with a B.Pharm.(Hons) and then went on to work for a Ph.D. (University of London) which he received in 1973. $\mathrm{He}$ spent two years as a Research Fellow in the Department of Pharmacology, University of Birmingham, before moving to Nottingham in 1974 .

Geoff Bramwell's research work centred on the pharmacology of neurones in the central nervous system and he was interested in the interactions between neurotransmitter substances and drugs with central effects, utilising the technique of microiontophoresis. His early work in Donald Straughan's department at the School of Pharmacy, was to investigate the actions of drugs on 5-hydroxytryptamine-containing neurones in the brain, particularly cells in the raphe nuclei. The drugs he studied included LSD and, although this work resulted in only a small number of publications, he made a significant contribution in this area. On moving to Birmingham. Bramwell became involved in studies on the actions of opiate drugs on single neurones in the brain and he continued this work at Nottingham after first setting up a laboratory for electrophysiological studies. He extended his studies to include the opioid peptides and latterly became interested in the quantitative aspects of neuronal responses to locally applied pharmacological agents. He published in the British Journal of Pharmacology, Brain Research and Neuropharmacology, and his work was becoming known internationally at the time of his death.

Very few of his friends and colleagues knew of his illness and, in spite of the difficulties caused by the therapy, he remained cheerful and was strenuously trying to keep his research work going. He is survived by his wife, Alison.

P. B. Bradley 